\title{
Structure, function and cross-scale properties of landscape boundaries - a case study of the Płock area
}

\begin{abstract}
The paper describes features of landscape boundaries in the lowland landscape of Poland and verifies their cross-scale properties. The diversity of lithology, morphometry and land use was taken into account by delimitation of the boundaries. A scale of 1:50 000 was set as the basis. Three structural features (length, contrast and sinuosity) and two functional features (permeability and stability) were examined.

The boundaries within the research area are typically of average length, low sinuosity, high permeability and low stability. A high correspondence between the diversity of abiotic components and land use is observed, resulting in a large number of high-contrast boundaries. However, this feature does not necessarily mean that these patterns are cross scale and can be applied at a higher level of landscape hierarchy.

A geochemical/typological and regional order has been explored to describe properties of landscape boundaries for different spatial scales. Only the first of the listed orders corresponds to diversification of boundary features.
\end{abstract}

Keywords

Landscape $\cdot$ boundary $\cdot$ structural features $\cdot$ functional features $\cdot$ spatial hierarchy

(c) University of Warsaw - Faculty of Geography and Regional Studies

\author{
Sylwia Kulczyk \\ Institute of Socio-Economic Geography \\ and Spatial Management \\ Faculty of Geography and Regional Studies \\ University of Warsaw \\ e-mail: skulczyk@uw.edu.pl \\ Received: 3 October 2013 \\ Accepted: 3 December 2013
}

Introduction

Boundaries are an important element of the landscape mosaic as they can determine interactions between its different elements (Cadenasso et al. 2003). Identifying their character helps to understand landscape-determining mechanisms (Forman, Moore 1992). Characteristics of the boundaries relate to landscape stability and biodiversity (Farina 1998), agricultural production (Jagomagi and Mander 1982), global climate changes (Weinstein 1992), economic and social development (Desaigues 1990), human mindset and physiology (Jagomagi, Mander 1992), as well as visual attractiveness (Śleszyński 1997).

Landscape is a universal concept that is used in various research areas. The same term can address heterogeneous mosaics on any scale (Cadenasso et al. 2003). This concerns all landscape elements - patches, matrices, corridors and their boundaries. Thus, the clear description of assumptions and criteria adopted for their analysis in a particular case is crucial (Pietrzak 1998; Fortin et al. 2000).

However, a spatial scale of research influences not only methods used, but also the way the general concept is understood. According to Cadenasso et. al. (2003), boundaries research on different scale levels lacks consistency due to the absence of a shared terminology and a common conceptual framework. Identifying features that control boundary characteristics at different spatial scale levels could be helpful in land management and planning.

The paper describes the structural and functional features of the boundaries of landscape units in the lowland, agricultural landscape of central Poland. It also verifies dependencies of scale in boundary characteristics. Are there any universal boundaries which exist and retain their features in different spatial scales, or are they purely theoretical constructions, adequate for cartographic methodologies of a defined scale?

\section{Methods}

The analysis was conducted for an area of $3600 \mathrm{~km}^{2}$ of the lowland landscape in the vicinity of Płock. A detailed description of the study area can be found in Richling, Malinowska and Lechnio (2005) and other papers published herein.

The presented analysis concerns the boundaries of landscape patches delimited using the leading factors method (Richling 1992). The diversity of lithological, morphometrial and land use features was taken into account in the process of boundary delimitation (for details see Richling, Malinowska, Lechnio 2005 and other papers published herein). A scale of 1:50000 was set as the research basis. Every segment separating different landscape patches is considered to be an individual boundary and is represented as a vector line. For each one, its origin, structural and functional features have been described. The analysis was conducted in ArcGis 9.3 software.

The origin of any boundary is the basic factor that influences its nature (Jacquer, Maruca, Fortin 2000). According to the type and number of components whose change results in the boundary's existence, nine types of boundaries are distinguished. They include lithological, morphological, land use, morpho-land use, litho-land use, litho-morphological, complex (when all components change), anthropogenic (boundaries of built-up and highly transformed areas) and water boundaries. Their origin has been taken into consideration in the analysis of their structural and functional features. 
Three structural features were taken into account: length, contrast and sinuosity. The length of boundaries was measured with an accuracy of $1 \mathrm{~m}$. The contrast is defined as the number of features that change at the boundary. The original Richling (1974) method was transformed in a two-step procedure. Features of each component were classified into consistent groups. The contrast is the total number of changes within and outside each group. Water and anthropogenic boundaries are considered to be high-contrast. The sinuosity index (the ratio of the straight line between the ends of the section to its length) was calculated for all boundaries, except round objects.

Two functional features - permeability and stability - were described. These were estimated using semi-quantitative methods previously verified in other areas of Poland (Kulczyk 2005,2006 ). Permeability is evaluated for a stream of passively transported matter. The slope and the position of a border within the relief profile are considered accelerating factors. The physical composition of the lithological component and the height of vegetation were treated as inhibitory factors (Soczawa 1978; Wiens 1992; Jagomagi, Mander 1992). Permeability was calculated with the following equation:

$$
P=\left(p_{-} m\right)-\left(p_{-} l+p_{-} v\right)
$$

where $P$ - permeability index, $\quad p \_m$ - relief-dependent rate of matter transport, $p$ I - factor of lithological difference between adjacent units, $p_{-} \bar{v}-$ factor of land use difference between adjacent units. A detailed description of the method is to be found in Kulczyk 2005, 2006 and 2013. Stability is defined as the absence of temporal changes in boundary location and internal structure. In this case, the semi-quantitative method was also used. Lithology and relief are evaluated for their resistance to erosion. For land use, the level of human influence is assessed. Boundaries of plains built of resistant material (with clays being the most resistant within the researched area), covered by forest are assumed to be the most stable. The stability of the boundary relates to the least stable components that change. However, every component has its own dynamics, with land use changes recognized to be the fastest, and lithological changes the slowest (Miller, Petlin, Galambosz 1982). A ratio of 1:4:10 is assumed. Thus, the stability is described as:

$S=\frac{10[l]+4[m]+[v]}{k}$

where [l] - lithological stability, [m] - morphological stability, [v] - land use stability, $\mathrm{k}$ - number of changing features. A detailed description of the method is to be found in Kulczyk 2005, 2006 and 2012.

Boundaries of landscape units delimited in the scale 1:50000 can be grouped on upper hierarchical levels. Three ways to organize them are considered: typological, regional and geochemical. With regard to the researched area, a typological division into lowland and river valley landscape corresponds to the geochemical autonomous and subordinated areas. Boundaries that exist within the autonomous or subordinated area are considered to be the lower level, and those that divide both types of areas as the upper level ones. Boundaries of the microregions delimited by Richling, Malinowska and Lechnio (2005) are recognized as the upper level of the regional hierarchy. For each order, boundaries of the upper level have been characterized based on the features derived from the lower level. In order to present the dependence of a boundary's characteristics on its topographical or regional position, the diversity index $D=\frac{\% p}{\% t}-1$ (D) has been calculated, here $\% p$ - share of boundaries with desired characteristics from sections that form the upper level of the hierarchy, \%t - share of boundaries with desired characteristics from all identified 1:50 000 boundaries.
Results

Within the researched area, 3,748 landscape boundaries were identified. Their origin is presented in Figure 1.

The length of the boundaries varies between the minimal detectable at the 1:50 000 scale $(26 \mathrm{~m})$ and $18011 \mathrm{~m}$. Very short boundaries $(26-1047 \mathrm{~m})$ constitute $28 \%$ of the total; short boundaries (1048-2308 $\mathrm{m}$ ) account for $19 \%$. The average-length boundaries (2309-4167 m, 48\%) are most frequent. Long (4168$7579 \mathrm{~m})$ and very long (7580-18011 m) boundaries are rare $(4 \%$ and $1 \%$, respectively). Figure 2 shows differences of boundary longitude depending on their origin. The shorter boundaries are typical for those of land use origin and for boundaries of areas significantly modified by human influence. The longer ones typically include water, litho-land use, morphological or lithological boundaries.

Forty percent of the analyzed boundaries are high-contrast, whereas $37 \%$ represent average and $23 \%$ low contrast. The sinuosity index remains low. The lowest range (very small: 1.02.5 ) accounts for $45 \%$ of the total. The index varies between 2.6 and 6.4 (small) for $31 \%$ of boundaries, $6.5-12.4$ (average) for $16 \%$ of boundaries and $12.4-21.5$ (big) for $7 \%$ of boundaries. The index is 21.6 (very big) or higher for just $1 \%$ of the total. Figure 3 shows the origin of the boundaries depending on their sinuosity index. The lowest sinuosity characterizes land use, morphological, lithological and litho-land use boundaries, whereas the higher level is typical for the built-up, water and lithomorphological boundaries.

The analysis of functional features does not include boundaries of strongly transformed and water areas, so the total number of analyzed objects was 3,423 . Their permeability can be described as average (permeability index 3-4) to high (permeability index 5-9) (41\% and $47 \%$ of the total, respectively). The high permeability is typical for litho and morphological boundaries, whereas the low permeability (permeability index 0-2) pertains to litho-land use boundaries (Fig. 4).

Seventy-five percent of the boundaries have a low stability index (5 to 14 ) and only $5 \%$ are those of high stability (stability index 33 to 45 ). The low stability index is typical for complex, litholand use and morpho-land use boundaries. Morphological and lithological boundaries are usually the highly stable ones (Fig. 5.).

An analysis of relations between the hierarchical level of a boundary and its features was performed for boundaries representing geochemical/typological (topographical position) and regional (microregions) orders. As far as the topographical order is concerned, $62 \%$ of investigated boundaries represent the lower level and $38 \%$ belong to the higher level of the hierarchy. As for the regional order, only $6 \%$ of the investigated boundaries belong to the upper level of the hierarchy.

The significant differentiation of all features corresponds to classifying individual boundaries into lower and upper hierarchical levels according to their topographical position. The values of the diversity index are presented in Figure 6.

The boundaries of lower level are shorter and of lower contrast. There are no significant differences between the two groups as far as sinuosity is concerned. The boundaries of the upper level that separate autonomous and subordinated areas represent higher permeability and lower stability due to their placement within the morphological profile. Boundaries classified as the higher rank of the geochemical/typological hierarchy separate autonomous and subordinated areas. They consist of a large number of average-contrast boundaries. A high number of straight, long boundaries has been identified for this group. However, the share of shorter and curvilinear objects is also significant. Geochemical/typological boundaries of higher ranks are little more permeable and significantly less stable than the mean for all analyzed boundaries. 

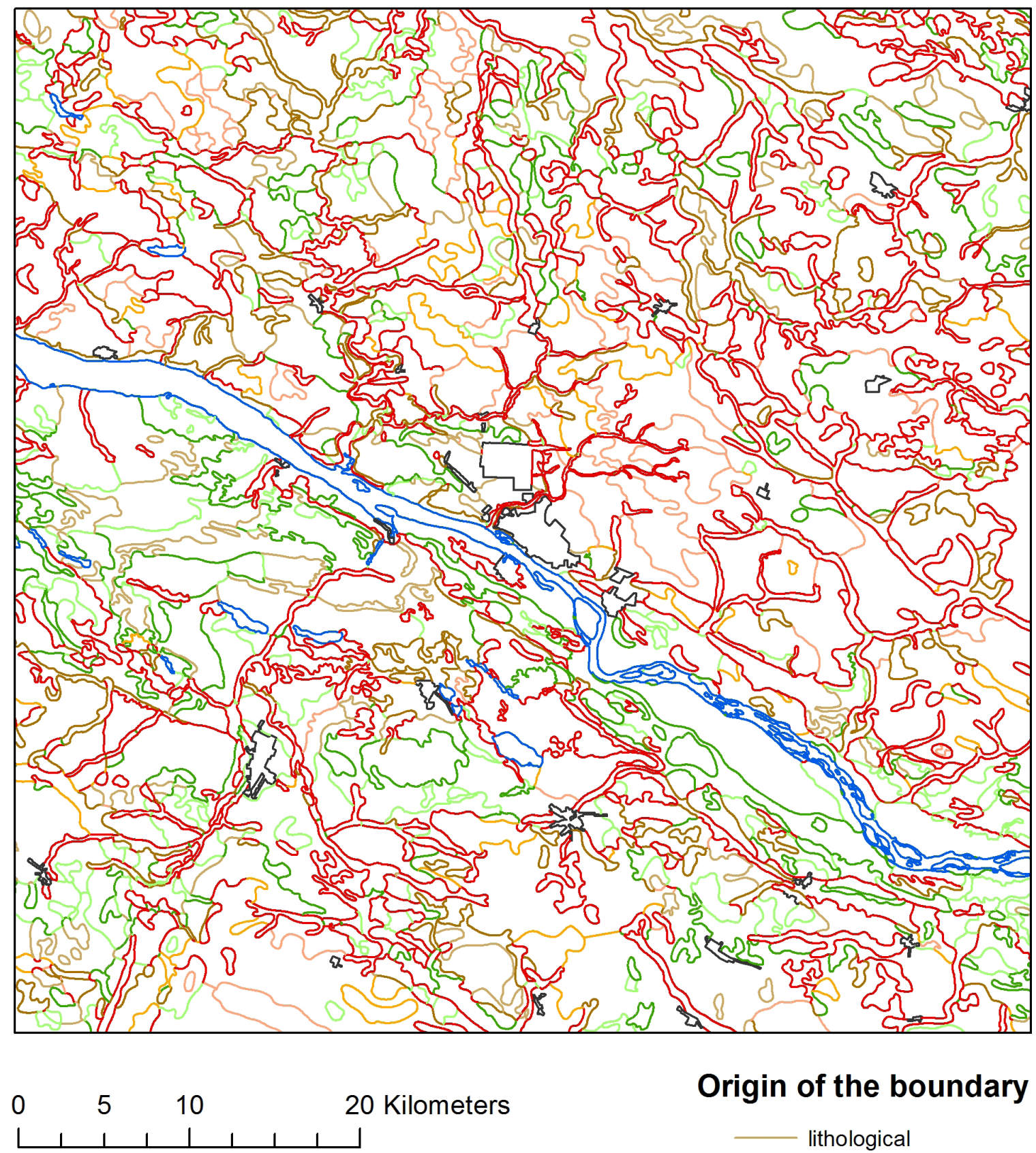

Origin of the boundary

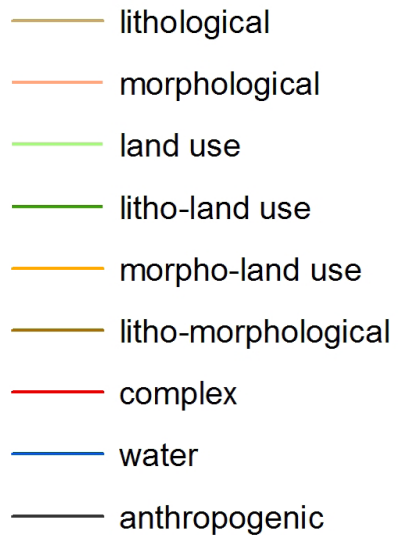

Figure 1. The origin of landscape boundaries within the Płock area 


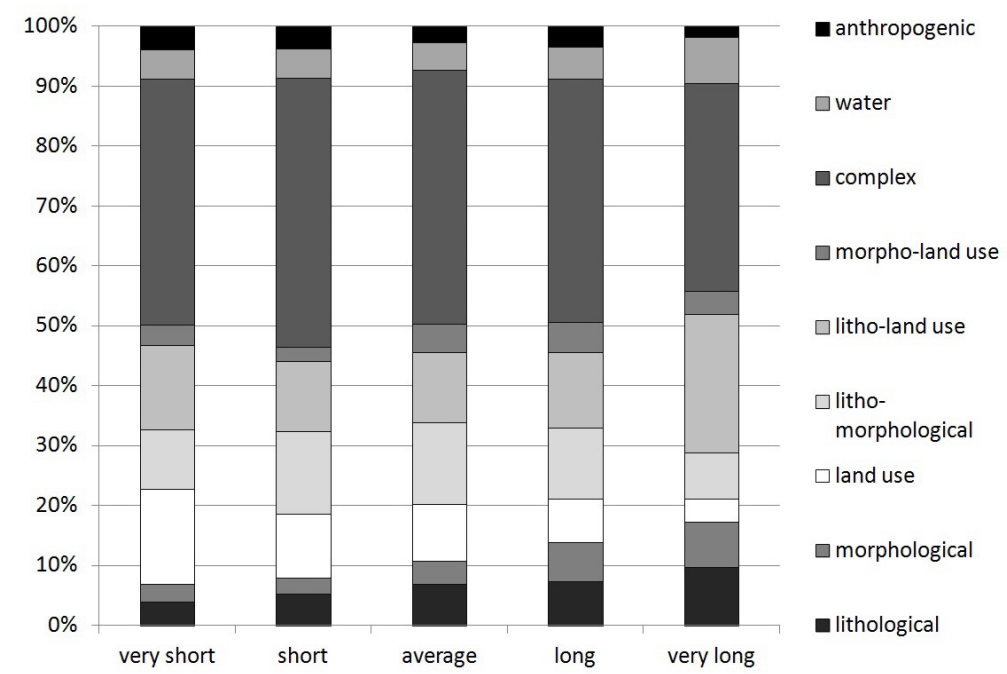

Figure 2. Length of the boundaries according to their origin

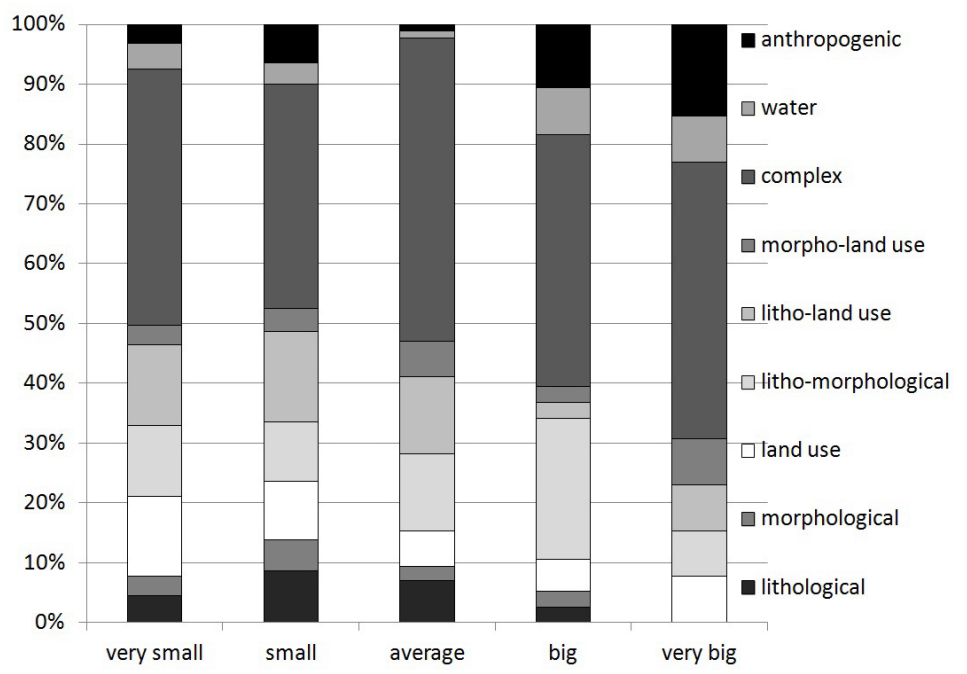

Figure 3. Sinuosity of the boundaries according to their origin

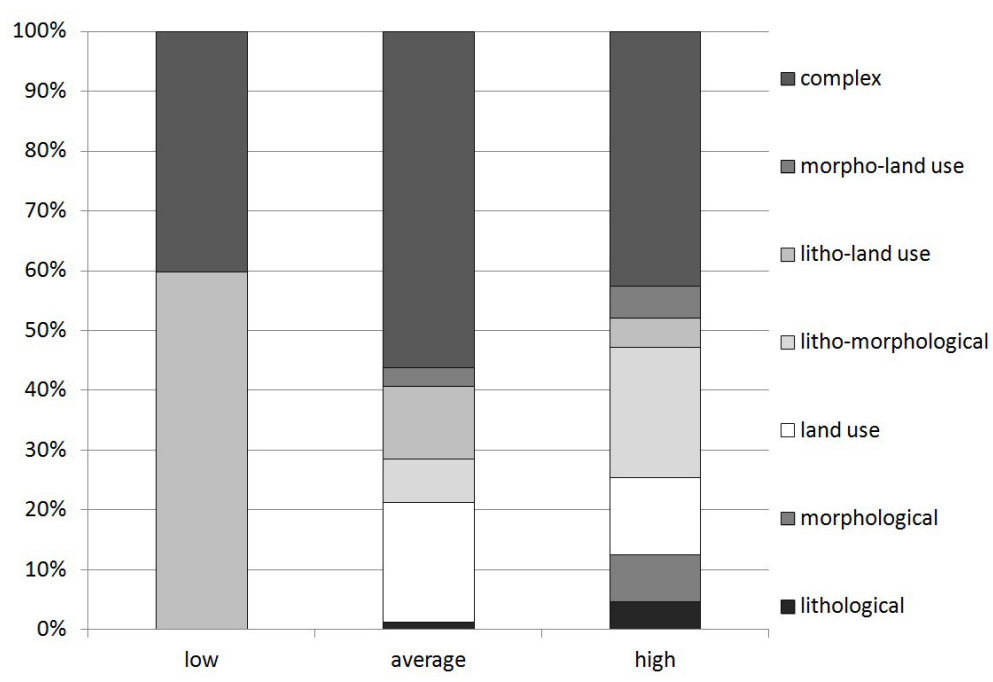

Figure 4. Permeability of the boundaries according to their origin 


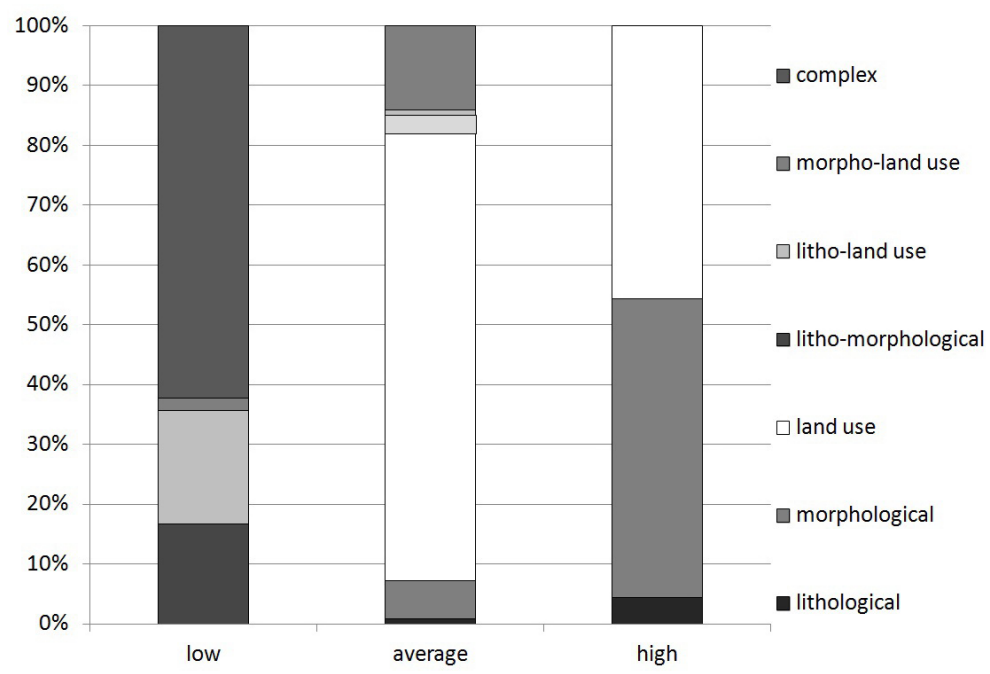

Figure 5. Stability of the boundaries according to their origin
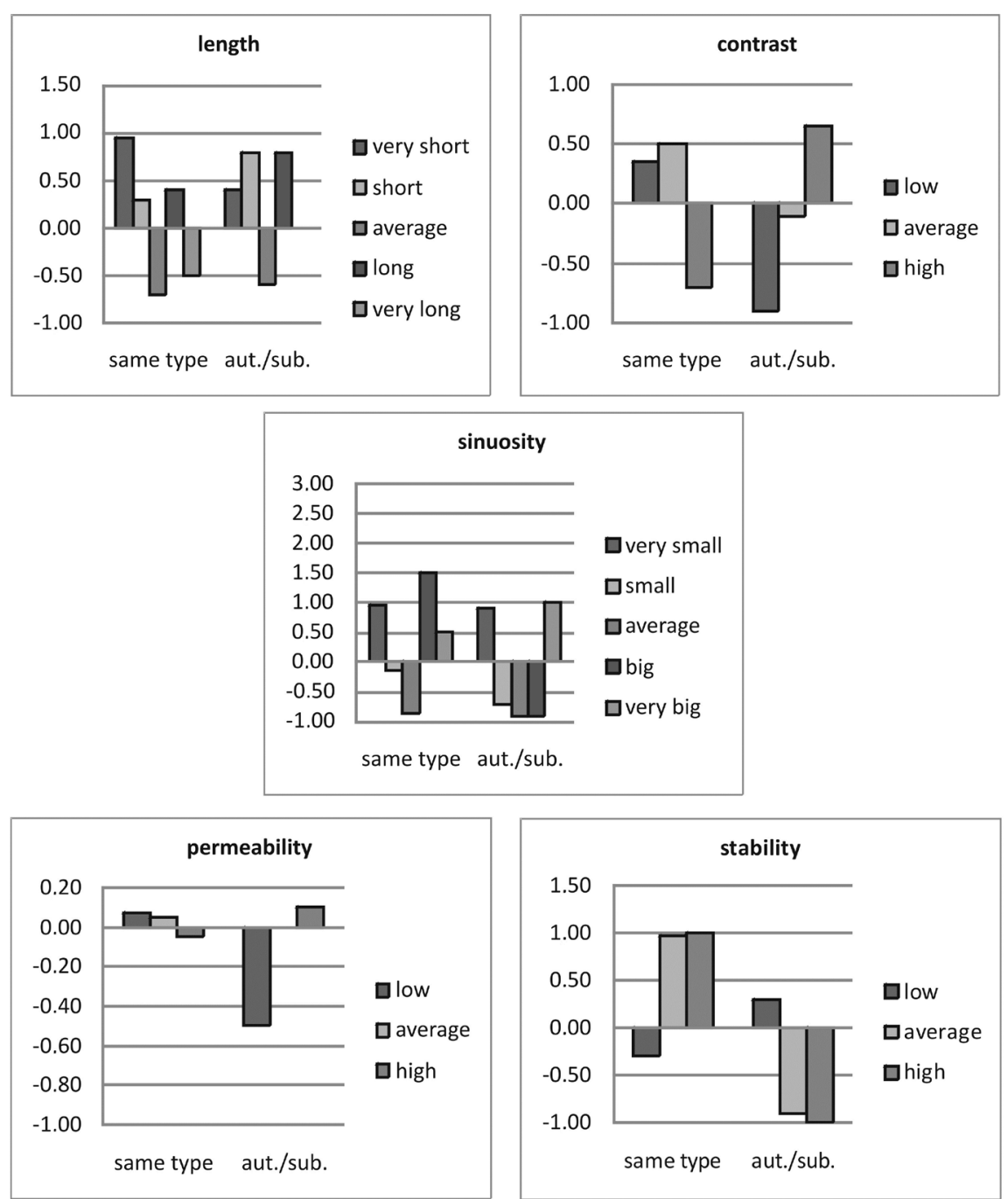

Figure 6. Boundary characteristics according to their topographic position 

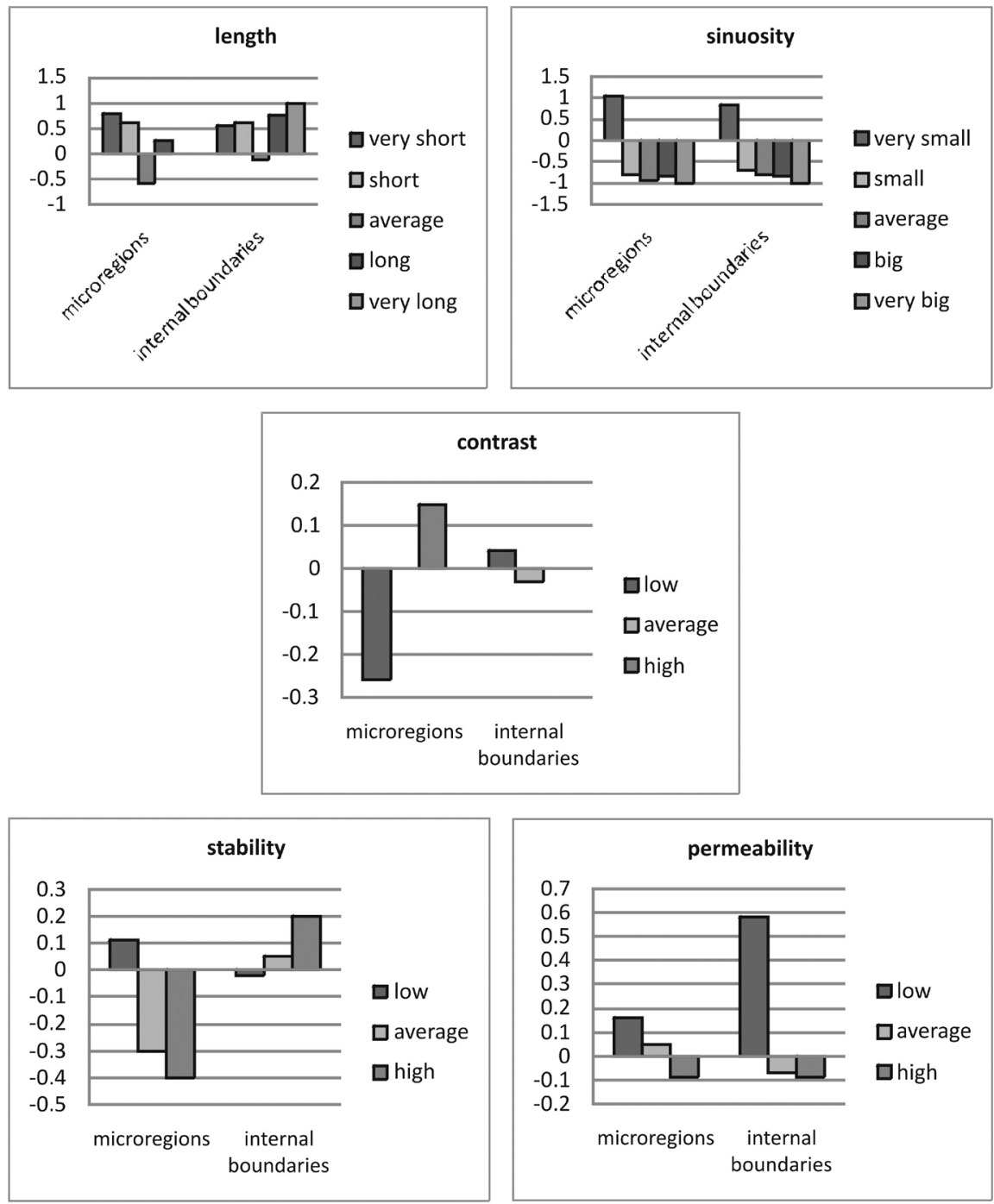

Figure 7. Boundary characteristics according to their regional position

A comparison of features of the boundaries that correspond to different regional hierarchy levels (limits of microregions and other boundaries) does not show any significant differences (Fig. 7).

\section{Discussion and conclusions}

Compared to other types of landscapes in Poland, the area of study seems to be monotonous. However, diversity analysis of the three leading components has unveiled its heterogeneity. Landscape boundaries within the area are not only numerous, but also vary in terms of their structural and functional characteristics.

Morphology is the key factor that shapes the landscape and its boundaries in the analysed area. The dominant morphological unit, the plain, is cut by large valleys (Wisła, Skrwa), which significantly contribute to the landscape diversity. A high number of complex boundaries proves that the agricultural use of terrain corresponds to its natural properties. Moreover, it indicates that the investigated boundaries are not just lines on a map, invented by researchers, but real objects.

Cadenasso et. al (2003) argue that the landscape boundary is a cross-scale concept. Its properties don't depend on the scale of research; thus, high level boundaries can also be detected on the detailed scale level. The analysis does not confirm the universal character of this statement. Regional hierarchy is not reflected by boundary characteristics. However, it should be underlined that it is not possible to compare both studies due to significant methodological differences. Further research on the problem is needed. Previous analyses carried out for different landscape types (Kulczyk 2004) indicate that, in lowland landscapes, regional boundaries resemble belts. Their linear cartographic image is just an approximation that is needed for a concise presentation of the landscape mosaic (Armand 1980).

The only type of landscape boundaries whose features remain clear on a large scale are those of the geochemical/ typological order that indicate limits between autonomous, transit and subordinated areas. Therefore, these types of boundaries should be treated as the key to the analysis of lowland landscapes.

\section{Acknowledgement}

The paper was prepared under the research project of the Ministry of Science and Higher Education - project number $\mathrm{N}$ N305 322135 "Hierarchical model of the natural system and its use for geo- and biodiversity assessment and forecasting." 
Armand, DL 1980, Nauka o krajobrazie [The Science of Landscape], PWN, Warszawa.

Cadenasso, ML, Pickett, STA, Weathers, KC \& Jones, CG 2003, 'A framework for a theory of ecological boundaries', BioScience, vol. 53, pp.750-758.

Desaigues, B 1990, 'The socio-economic value of ecotones' in The ecology and management of aquatic-terrestrial ecotones, eds RJ Naiman \& H Décamps, MAB, UNESCO, Paris.

Farina, A 1998, Principles and Methods in Landscape Ecology, Chapman\&Hall, London.

Forman, RTT \& Moore, PN 1992, 'Theoretical Foundations for Understanding Boundaries in Landscape Mosaics' in Landscape Boundaries, eds AJ Hansen \& F di Castri, Ecological Studies, vol. 92, Springer-Verlag, New York.

Fortin, MJ, Olson, RJ, Ferson, S, Iverson, L, Hunsaker, C, Edwards, G, Levine, D, Butera, K \& Klemas, V 2000, 'Issues related to the detection of boundaries', Landscape Ecology, vol. 15, pp. 453-466.

Jacquer, GM, Maruca, S \& Fortin, MJ 2000, 'From fields to objects: A review of geographic boundary analysis', Journal of Geographical Systems, vol. 2, pp. 221-241.

Jagomagi, JE \& Mander, JE 1982, 'Poniatie ekotona i wozmożnosti jego uspołzowania pri ocenkie teritori' in Issliedowanie $i$ kartografirowanie landszafta, Acta et Comentationes Universitatis Tartuensis, Tartu.

Kulczyk, S 2004, 'Landscape Boundaries - Belts or Lines? Examples from Southern and Northern Poland', Miscellanea Geographica, vol.10, pp. 19-27.

Kulczyk, S 2005, 'Funkcjonalne cechy granic krajobrazowych na przykładzie Wigierskiego Parku Narodowego' [Functional Features of Landscape Boundaries - example of Wigierski National Park], Prace i Studia Geograficzne, vol. 36, pp. 48-64.

Kulczyk, S 2006, 'Caracterizacíon de los limites naturales: un caso del area de Chroberz' [Characteristisc of natural boundaries: case study of Chroberz area], Revista Electronic@de Medioambiente UCM, vol. 2, pp. 104-119,
Available from: <http://revistas.ucm.es/index.php/MARE/ article/view/MARE0606220104A/15259> [29.08.2013].

Miller, GP, Petlin, WN \& Galambosz, J 1982, 'O dinamikie i ustojcziwosti prirodnych tierritorialnych kompleksow' [On dynamic and stability of natural spatial complexes], Woprosy Gieografii, vol. 121.

Pietrzak, M 1998, Syntezy krajobrazowe - założenia, problemy, zastosowania [Landscape Syntheses - Assumption, Problems, Applications], Bogucki Wydawnictwo Naukowe, Poznań.

Pietrzak, M 2000, ‘Granice krajobrazowe - fikcja czy rzeczywistość?' [Landscape boundaries - fiction of reality?], Problemy Ekologii Krajobrazu, vol. 7, pp.189-197.

Richling, A 1974, Analiza struktury środowiska geograficznego i nowa metoda regionalizacji fizycznogeograficznej (na przykładzie województwa białostockiego), manuscript.

Richling, A 1992, Kompleksowa geografia fizyczna, Wydawnictwo Naukowe PWN, Warszawa.

Richling, A, Malinowska, E \& Lechnio J 2005, 'Typologia i regionalizacja krajobrazu terenów w strefie oddziaływania Płockiego Zespołu Miejsko-Przemysłowego' [Typology and regionalisation of landscape within the zone of influence of Płock urban-industrial complex] in $Z$ problematyki Funkcjonowania Krajobrazów Nizinnych, eds A Richling \& J Lechnio, WGSR UW, Warszawa.

Śleszyński, TP 1997, Ocena atrakcyjności wizualnej krajobrazu okolic Pińczowa, master thesis, Departament of Geoecology, WGSR UW.

Soczawa, WB 1978, Wwiedienije w uczenije o gieosistemach, Nauka, Nowosybirsk.

Weinstein, DA 1992, 'Use of Simulation Models to Evaluate the Alteration of Ecotones by Global Carbon Dioxide Increases', in Landscape Boundaries, eds AJ Hansen \& F di Castri, Ecological Studies, vol. 92, Springer-Verlag, New York.

Wiens, JA 1992, 'Ecological Flows Across Landscape Boundaries: A Conceptual Overview' in Landscape Boundaries, eds AJ Hansen \& F di Castri, Ecological Studies, vol. 92, Springer-Verlag, New York. 